\title{
External fixation to correct tarsal-metatarsal fracture in rock pigeon (Columba livia)
}

\author{
Leandro Almeida Rui ${ }^{1}$, Diego Carvalho Viana ${ }^{2 *}$, Adriano Barile Dora ${ }^{1}$, Paula Fratini ${ }^{1}$
}

10.1590/0034-737X201764010004

\begin{abstract}
Orthopedic conditions, such as bone fractures, are very common in avian medicine. External fixators have been considered the gold standard for birds, since they allow early movement of the limbs and minimal invasive surgery. Fractures in several bones have been successfully treated in pigeons. However, to the best of our knowledge, this case represents the first report of successful surgical repair of tarsal-metatarsal fracture in rock pigeon. External fixator was made with four $24 \mathrm{G}$ catheters, being inserted manually proximal and distal to the fracture and connected with polymerizable acrylic. Radiographic consolidation of fracture was observed 60 days post-surgery and anti-inflammatory and antibiotic protocols were successful on avoiding pain and infection during surgery and bone healing.
\end{abstract}

Key words: rock pigeon; avian orthopedics; external fixator; tarsal-metatarsal fracture; polymerizable acrylic.

\section{RESUMO}

\section{Fixação externa para correção de fratura tarsal-metatarsal em pombo-comum (Columba livia)}

Afecções ortopédicas são muito comuns na medicina aviária, tais como fraturas ósseas. Os fixadores externos estão sendo considerados o "gold standard" para aves, uma vez que permitem retorno rápido ao movimento dos membros através de cirurgia minimamente invasiva. Fraturas em vários ossos haviam sido tratadas com sucesso em pombos. No entanto, este caso representa o primeiro relato de tratamento cirúrgico bem sucedido em fratura tarsalmetatarsal desta espécie. Um fixador externo foi confeccionado com quatro cateteres $24 \mathrm{G}$, sendo inseridos manualmente proximal e distalmente à fratura, e conectados com acrílico polimerizável. A consolidação radiográfica da fratura foi observada aos 60 dias de pós-operatório, e os protocolos de anti-inflamatórios e antibióticos foram efetivos em evitar dor e infecção durante a cirurgia e a cicatrização óssea.

Palavras-chave: pombo doméstico; ortopedia aviária; fixador externo; fratura tarsal-metatarsal; acrílico polimerizável.

\footnotetext{
Submitted on April 14 $4^{\text {th }}, 2014$ and accepted on December $19^{\text {th }}, 2016$

${ }^{1}$ Universidade de São Paulo, Faculdade de Medicina Veterinária e Zootecnia, São Paulo, São Paulo, Brazil. leandro.rui@usp.br; arca24h@gmail.com; paulafratini10@gmail.com ${ }^{2}$ Universidade Estadual da Região Tocantina do Maranhão (UEMASUL), Imperatriz, Maranhão. diego_carvalho_@hotmail.com

*Corresponding author: diego_carvalho_@ hotmail.com
} 


\section{INTRODUCTION}

In recent years, clinical care to wild species has increased due to an interest in wildlife preservation and in the use of these as companion animals, among them the birds (Bolson et al., 2008).

Several methods have been used for treatment of fractures in birds. However, due to variations in size, weight, and conformation of different species, as well as the peculiar bone anatomy, the high incidence of complicated fractures and differences in functional requirements between species and individuals, it is not possible yet to establish an ideal method of osteosynthesis for long bones in these animals (Alievi et al., 2002). In this work, we aimed to describe type II external skeletal fixator for the reduction of diaphyseal fractures in tarsus of domestic pigeons, being evaluated by clinical and radiographic examinations.

\section{MATERIAL AND METHODS}

A rock pigeon (Columba livia) was assisted in the veterinary hospital Tigre D’ Água (Vila Matilde, São Paulo, Brazil), suffering from functional disability in right pelvic limb. On physical examination, burn and fracture in the tarsal-metatarsal region (Figure 1A) were observed. The animal was medicated with $3 \mathrm{mg} / \mathrm{kg}$ of antiinflammatory ketoprofen $10 \%$ (Ketojet $^{\circledR} 50 \mathrm{ml} / 100 \mathrm{mg}$, Agener União, São Paulo, SP, Brasil) and $5 \mathrm{mg} / \mathrm{kg}$ of antibiotic enrofloxacin 2.5\% (MSD Saúde Animal, São Paulo, SP, Brasil), both intramuscularly. Bandage and splint were made with tape, over a gauze with saline solution to prevent bone dehydration until the moment of surgery (Figure 1B).
For surgical procedure, the animal was taken to the surgical center of the hospital after $2 \mathrm{~h}$ of fasting. Preanesthetic medication was made with $4 \mathrm{mg} / \mathrm{kg}$ morphine (Dimorf®, Cristalia, Porto Alegre, RS, Brasil) and $15 \mathrm{mg}$ / kg ketamine (Agener União, São Paulo, SP, Brasil), both intramuscularly (Figure 2A). General anesthesia was induced by isoflurane in mask (Hoechst, Suzano, SP, Brasil) (Figure 2B) and subsequently maintained by isofluorane in orotracheal tube (Figure 2C). Blood pressure was monitored using Doppler placed in the carotid artery region (Figure 2D). Feathers of tibiotarsal and tarsalmetatarsal regions were removed by traction and surgical field was subjected to antisepsis with chlorhexidine gluconate 4\% (Vico Farma, Santa Maria, RS, Brasil). As a prophylactic measure, $5 \mathrm{mg} / \mathrm{kg}$ of enrofloxacin $2.5 \%$ (MSD Saúde Animal, São Paulo, SP, Brasil) were administered intramuscularly $30 \mathrm{~min}$ before the procedure.

With animal in dorsal recumbency, skin incision was made with scalpel in cranio-medial portion of the right tarsal-metatarsal, allowing bone exposure and osteosynthesis with implantation of type II external fixator. This fixator was composed of four $24 \mathrm{G}$ catheters (Nipro Medical Ltda, Sorocaba, SP, Brasil), two proximal and two distal to the osteotomy, in parallel (Figure 3A). Pins were inserted through medial surface of the bone using manual circular movements, piercing the skin, muscle, and bone. The ends were angled at $90^{\circ}$ to promote their approach and then pins were connected externally by two bars of polymerizable acrylic (Jet Acrílico, Artigos Odontológicos Clássicos, São Paulo, SP, Brasil), one in lateral and another in medial face of tarsal-metatarsal region of right hind limb (Figure 3B). After placement of lateral bar, and previous to the placement of medial bar, synthesis of subcutaneous

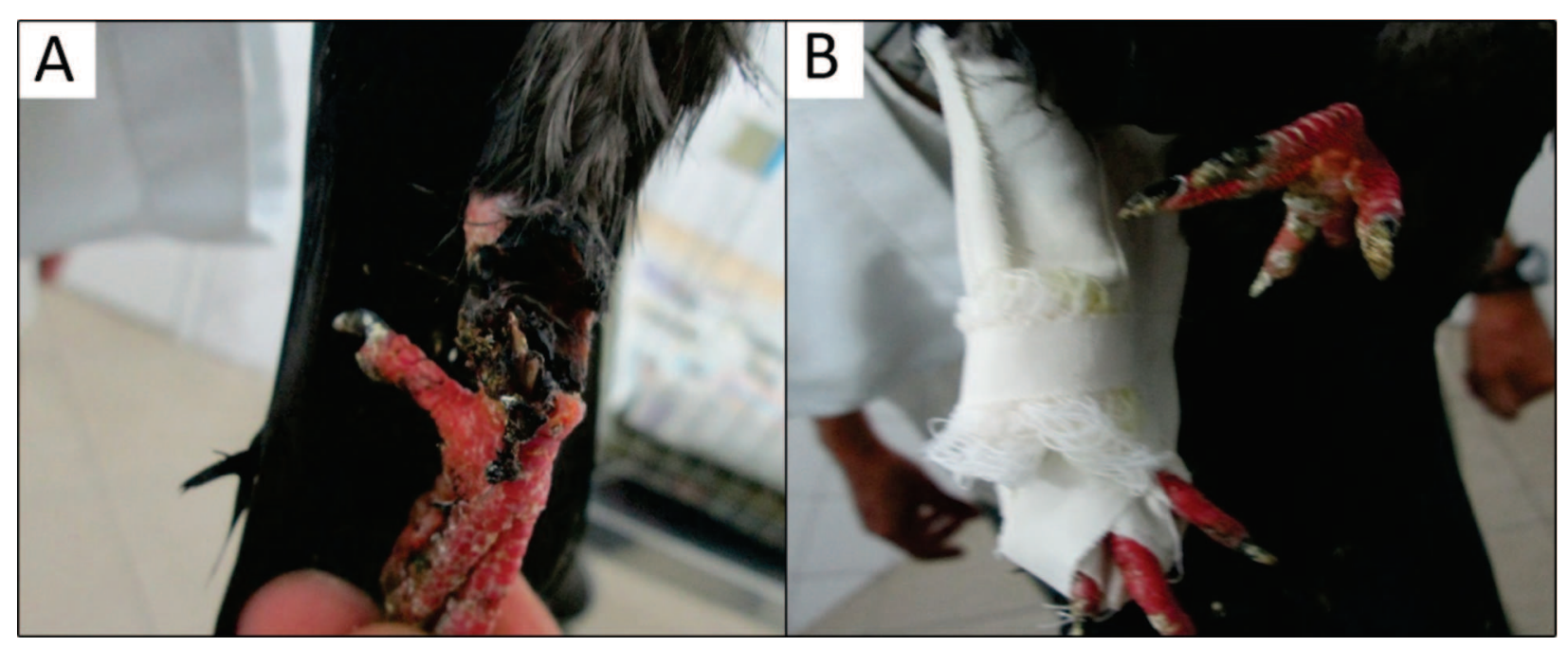

Figure 1: Orthopedic examination and limb immobilization.

A: Burn and fracture in tarsal-metatarsal region of right hind limb in rock pigeon (Columba livia).

B: Splint with tape and gauze soaked in saline solution in fracture region.

Rev. Ceres, Viçosa, v. 64, n.1, p. 025-030, jan/fev, 2017 
tissue and skin was made with mononylon 3-0 (Nylon Bioline, Goiania, GO, Brasil) in simple interrupted sutures.

After surgery, anti-inflammatory therapy was performed intramuscularly for three days, using ketoprofen in doses calculated by interspecific allometric extrapolation. Sterile gauzes soaked in saline solution were placed on the surgical site, replaced every other day until seventh postoperative day, when skin sutures were removed, and then every four days until bone healing.

After a period of 60 days, bone healing was confirmed by radiography (Figure 3C) and bird was anesthetized by combination of $3 \mathrm{mg} / \mathrm{kg}$ xylazine (Copazine ${ }^{\circledR}$, Mallinckrodt Veterinária Ltda, Cotia, SP) and $60 \mathrm{mg} / \mathrm{kg}$ ketamine (Francotar ${ }^{\circledR}$, Virbac, São Paulo, SP, Brasil) intramuscularly and the external fixator was removed with orthopedic pliers (Figure 3D).

\section{RESULTS AND DISCUSSION}

To the best of our knowledge, this case represents the first report of successful surgical repair of tibiotarsal fracture in a rock pigeon. The option for using external fixation was adequate, ensuring reduced surgical time, besides being an implant of low total weight - approximately $7 \%$ of the weight of the animal, an advantage also reported by other authors (Bush, 1983; Guzman et al., 2007; Ferraz et al., 2008).

Some studies have recommended placing pins with a divergent angle to maintain mechanical adhesion in the bone (Egger, 1991). An angle of $30-40^{\circ}$ between pins placed in each base of fragment has been suggested as the best way to join the bone. In this case, pins are placed perpendicularly across the bone, considering the pins

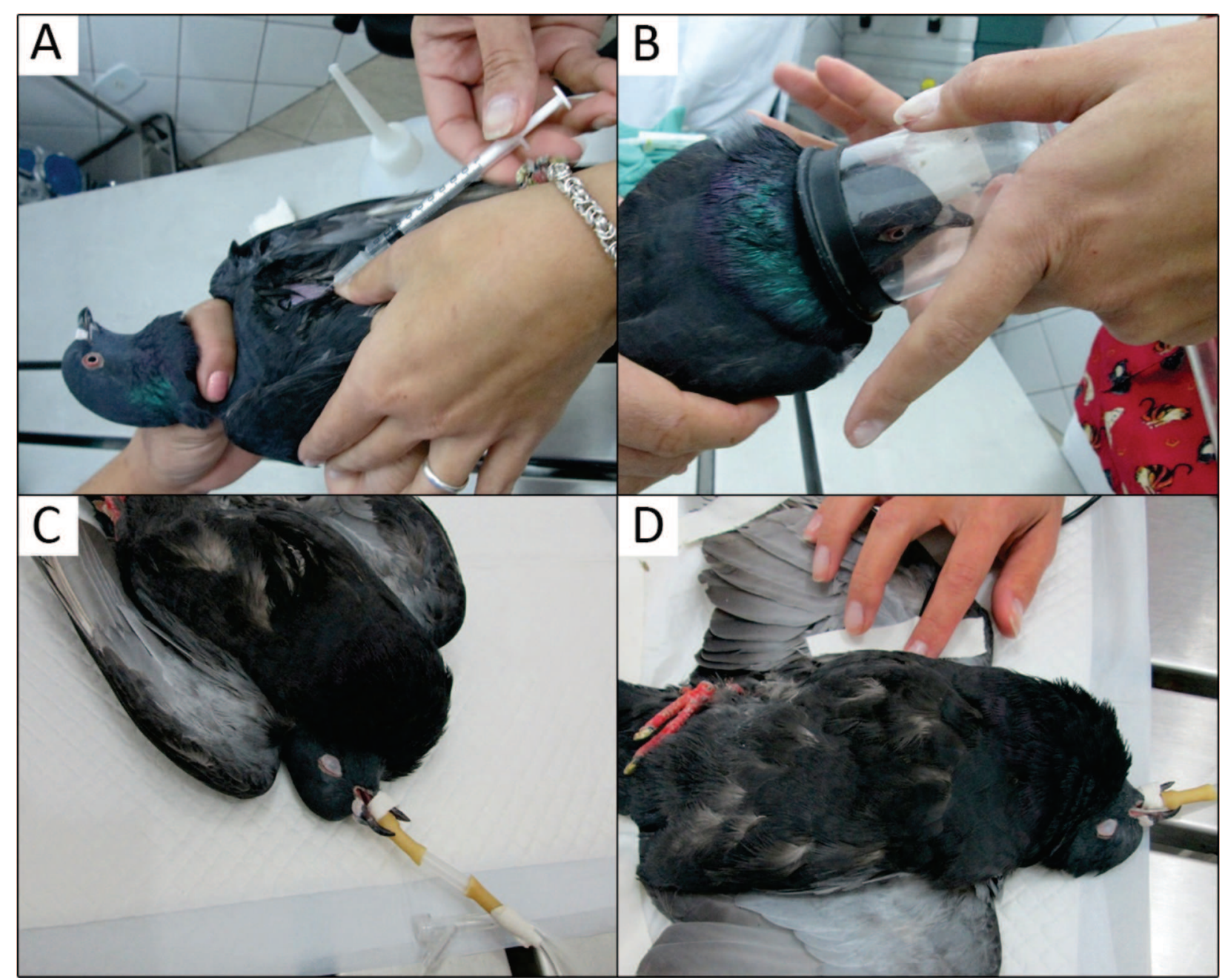

Figure 2: Anesthesia and anesthetic monitoring during osteosynthesis procedure in rock pigeon (Columba livia).

A: Intramuscular pre-anesthetic medication.

$\mathrm{B}$ : Induction of anesthesia by isoflurane in mask.

C: Maintenance of anesthesia and airways by orotracheal intubation.

D: Pressure monitoring by Doppler placed in carotid artery. 
as individual units, without considering the stiffness of external skeletal fixation, which has also been successfully reported in literature (Dernell et al., 1993; Degernes et al., 1998; Dalmolin et al., 2007; Pérez et al., 2008).

Research conducted previously with pigeons has presented a minimum adaptation period of 15 days for adjustment of diet, environment, and handling (Alievi et al., 2001; Gaiga \& Schossler, 2002; Leotte et al., 2004; Dalmolin et al., 2007). In this case, however, this time is doubled as observed before. Surgical approach is dorsal, between deltoid and propatagial muscles, being minimally invasive and providing necessary exposure of surgical site (Leotte et al., 2004; Bolson et al., 2008). Ventral access is avoided in order to preserve radial nerve (Gaiga \& Schossler, 2002). Knowledge of musculoskeletal anatomy of birds is essential for the success of osteosynthesis (Hatt, 2009).

There are reports of the use of drill (Alievi et al., 2008), oscillating saw (Wander et al., 2000), osteotome (Putney et al., 1983), and digital pressure in bird osteosynthesis (Williams et al., 1987; Alievi et al., 2002). In $27.77 \%$ of animals, oblique fractures occurred in osteotomy due to very thin cortex in this species (West et al., 1996). In this report, manual movements were used and problems related to lack of dense bone in metaphysis and presence of thin bone trabeculae along the length of bone, such as migration of the pin and rotational instability of fracture, were avoided due to the presence of perpendicular pins, which prevented the occurrence of such setbacks, as indicated by other authors (Kingsley, 1983; Dalmolin et al., 2007; Rahal et al., 2008).

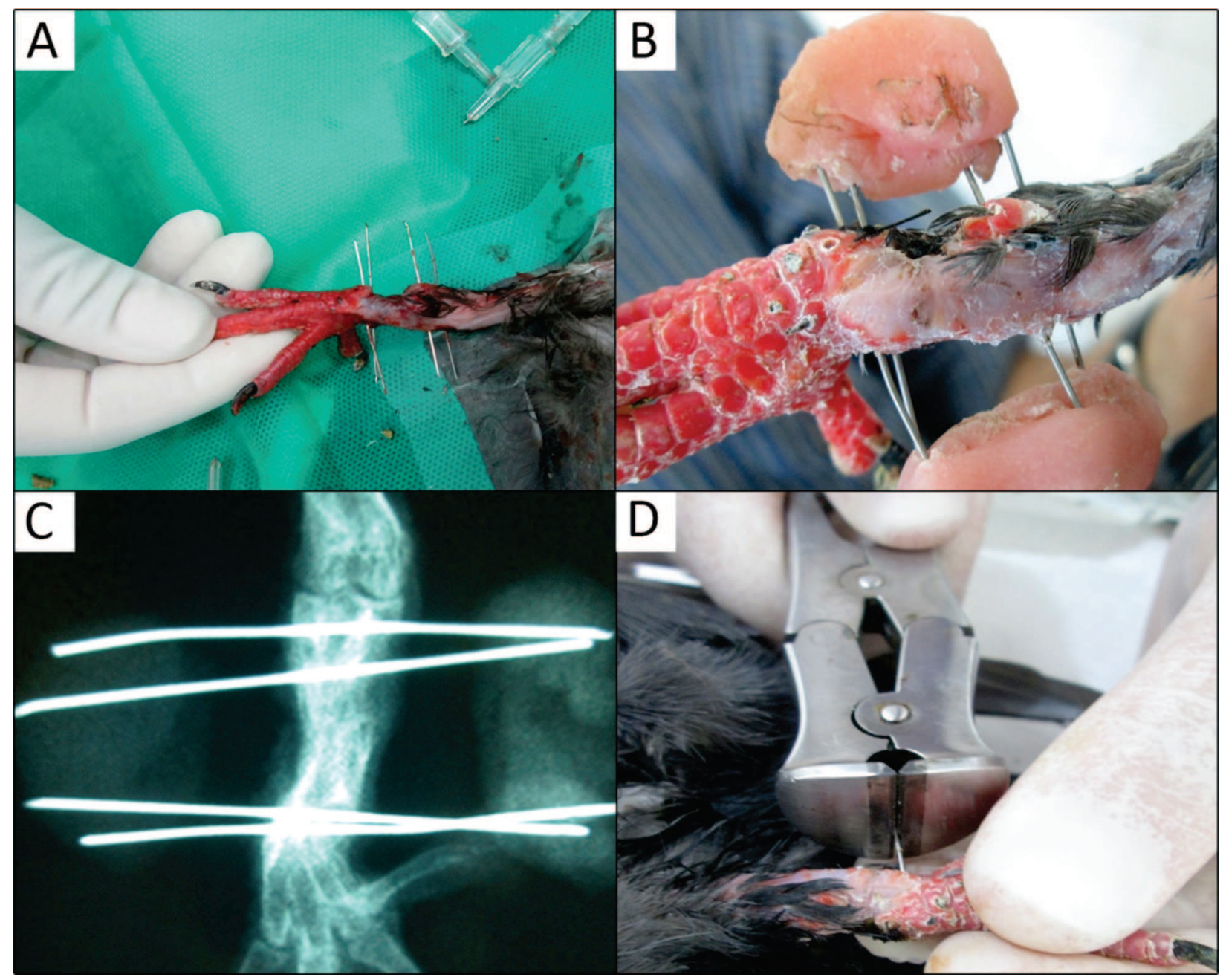

Figure 3: Osteosynthesis of tarsal-metatarsal fracture of the right hind limb in rock pigeon (Columba livia) with external fixation and post-surgical managament.

A: External fixator using four $24 \mathrm{G}$ catheters.

B: Connection of pings with polymerizable acrylic.

C: Radiographic image of bone healing.

D: Removal of pins with orthopedic pliers.

Rev. Ceres, Viçosa, v. 64, n.1, p. 025-030, jan/fev, 2017 
Anesthetic protocol was satisfactory, as reported for birds (Coles, 2007; Sá et al., 2012). However, some authors have stated that the used association may predispose to hypoxemia, hypercapnia, cardiovascular depression, and prolonged recovery in birds (Pascoe, 1985; Ludders et al., 1989; Ludders \& Matthews; 1996). Isoflurane has been reported to promote more stable anesthesia than halothane, being the anesthetic of choice in avian medicine, as well as in a broad range of species (Dohoo, 1990; Olkowski \& Classen, 1998; Rocha et al., 2009).

At 15 days post-surgery, radiographic examination showed no presence of callus or disappearance of fracture. During this period, animal had use of limb, which meets citations that radiographic consolidation happens later than clinical use of the limb (Williams et al., 1987; Wissman, 1999; Alievi et al., 2001). This supports findings that external fixators allow adequate movement of joints proximal and distal to the fracture, avoiding complications of non-use of the limb during bone healing (Pead \& Cardmichael, 1989; Dalmolin et al., 2007).

The antibiotic used (enrofloxacin) and the dose calculated by allometric extrapolation were efficient, avoiding postoperative infections, as observed by other authors (Leotte et al., 2004; Alievi et al., 2001; Gaiga \& Schossler, 2002; Dalmolin et al., 2007; Rocha et al., 2009). Some other studies have reported positive use of ampicillin (Alievi et al., 2008). Dose of ketoprofen and interval of application was satisfactory; despite the difficulty in evaluation of pain, the animal did not present any signs described in literature (Heard, 1997; Williams et al., 1987). Other studies have suggested the use of flunixin meglumine with no complications as anorexia, vomiting, or diarrhea (Jenkins, 1992; Rocha et al., 2009).

\section{CONCLUSIONS}

This case reports the first successful surgical treatment of tarsal-metatarsal fracture in rock pigeon, establishing an effective methodology for this condition using external fixator adapted for this species. Thus, we contribute to avian orthopedics, providing an effective technique for surgical correction of tarsal-metatarsal fractures.

\section{REFERENCES}

Alievi MM, Oliveira ANC, Ferreira PA, Traesel C, Guimarães LD, Flores F, Silva SF \& Schossler JEW (2008) Osteossíntese de úmero em pombos domésticos (Columba livia) associando-se pinos metálicos e polimetilmetacrilato intramedulares após osteotomia diafisária. Arquivo Brasileiro de Medicina Veterinária e Zootecnia, 60:1019-1025.

Alievi MM, Schossler JE, Hippler RA, Alves AS \& Silva JHS (2002) Redução fechada e fixação esquelética externa tipo I para tratamento de fraturas de tibiotarso em pombos domésticos (Columba livia). Arquivo Brasileiro de Medicina Veterinária e Zootecnia, 54:259-266.
Alievi MM, Schossler JE, Hippler RA, Alves AS, Pellegrini LC \& Langohr IM (2001) Redução fechada e fixação esquelética externa tipo II para o tratamento de fraturas de tibiotarso em pombos domésticos (Columba livia). Ciência Rural, 31:10191025 .

Bolson J, Schossler JEW, Machado G \& Zembrzuski FB (2008) Pino ósseo homólogo conservado em glicerina a $98 \%$ e hemicerclagem com fio poliglactina 910 na osteossíntese umeral de pombos domésticos. Ciência Rural, 38:1925-1931.

Bush M (1983) External fixation to repair long bone fractures in larger birds. In: Kirk RW (Ed.) Current Veterinary Therapy VIII. Philadelphia, Saunders. p.629-633.

Coles BH (2007) Essentials of Avian Medicine and Surgery. $3^{\text {th }}$ ed. Oxford, Blackwell Publishing. p.234-263.

Dalmolin F, Schossler JE, Bertoletti B, Vasconcelos A, Muller D, Schossler DR \& Gomes K (2007) Modificações do fixador externo para osteossíntese umeral em pombos domésticos. Ciência Rural, 37:443-449.

Degernes LA, Roe SC \& Abrams CF (1998) Holding power of different pin designs and pin insertion methods in avian cortical bone. Veterinary Surgery, 27:301-306.

Dernell WS, Harari J \& Blackketter DM (1993) A comparison of acute pull-out strength between two-way and one-way transfixation pin insertion for external skeletal fixation in canine bone. Veterinary Surgery, 22:110-114.

Dohoo SE (1990) Isoflurane as an inhalational anesthetic agent in clinical practice. The Canadian Veterinary Journal, 31:847850 .

Egger EL (1991) Complications of external fixation, a problemoriented approach. Veterinary Clinics of North America: Jornal of Small Animal Practice, 21:705-733.

Ferraz VCM, Ferrigno CRA, Cortopassi SRG, Lopes RS, Isaza R \& Kim S (2008) Avaliação radiográfica e de função de vôo após fixação de osteotomias distais do úmero em pombas (Columba livia), com modelo de fixador externo articulado. Pesquisa Veterinária Brasileira, 28:351-357.

Gaiga LH \& Schossler JE (2002) Osteossíntese de úmero por xenoenxerto ósseo preservado em mel em pombos domésticos (Columba livia). Ciência Rural, 33:709-715.

Guzman DS, Bubenik LJ, Lauer SK, Vasanjee S \& Mitchell MA (2007) Repair of a coracoid luxation and a tibiotarsal fracture in a bald eagle (Haliaeetus leucocephalus). Journal of Avian Medicine and Surgery, 21:188-95.

Hatt JM (2009) Osteosynthese bel Ziervögeln unter besonderer Berücksichtigung der externen Fixation] Osteosynthesis in avain surgery with special consideration on external fixation. Praktische Tierarzt, 90:398-406.

Heard DJ (1997) Anesthesia and analgesia. In: Altman RB (Ed.) Avian medicine and surgery. Philadelphia, Saunders. p.807-827.

Jenkins JR (1992) Avian soft tissue surgery - Part I. In: ACVS Veterinary Symposium, Miami. Proceedings, The American College of Veterinary Surgeons. p.631-633.

Kingsley CC (1983) A technique for repairing fractures of the humerus in small birds. Veterinary Medicine, 78:1093-1094.

Leotte AM, Raiser AG, Braga FA, Krauspenhar L, Camargo SF, Flores FN, Gomes K \& Scherer RS (2004) Fixação esquelética tipo Ia (unilateral-uniplanar) para osteossíntese diafisária de úmero em pombos domésticos (Columba livia). Ciência Rural, 34:1865-1870.

Ludders JW \& Matthews N (1996) Birds. In: Thurmon JC, Tranquilli WJ \& Benson GJ (Ed.) Veterinary anesthesia. $3^{\text {th }}$ ed. Baltimore, Lea \& Febiger. p.645-669. 
Ludders JW, Rode J, Mitchell GS \& Nordheim EV (1989) Effects of ketamine, xylazine, and a combination of ketamine and xylazine in pekin ducks. American Journal of Veterinary Research, 50:245-249.

Olkowski AA \& Classen HL (1998) Safety of isoflurane anaesthesia in high risk avian patientes. Veterinary Record, 143:82-83.

Pascoe PJ (1985) Avian anaesthesia. Veterinary Record, 116:5868.

Pead MJ \& Cardmichael S (1989) Treatment of severely comminuted fracture in a rabbit using a Kirschner-Ehmer apparatus. Journal of Small Animal Practice, 30:579-582.

Pérez EC, Seoane MS, Santamarina BV \& Cantalapiedra AG (2008) Comparison of holding power of three different pin designs for external skeletal fixation in avian bone: a study in common buzzard (Buteo buteo). Veterinary Surgery, 37:702-705.

Putney DL, Borman ER \& Lohse CL (1983) Methylmethacrylate fixation of avian humeral fractures: a radiographic histologic study. Journal of the American Animal Hospital Association, 19:773-782.

Rahal SC, Teixeira CR, Pereira-Junior OCM, Vulcano LC, Aguiar AJA \& Rassy FB (2008) Two Surgical Approaches to Fracture Malunion Repair. Journal of Avian Medicine and Surgery, 22:323330 .
Rocha LB, Conceição AM, Costa TAC, Mota J \& Santos AA (2009) Osteossíntese em fratura de epífise distal de úmero em papagaio verdadeiro (Amazona aestiva). Revista de Medicina Veterinária, 3:26-30.

Sá SS, Silva Filho JC, Souza FL, Franco RP, Scorsato OS \& Repetti CSF (2012) Osteossíntese tibial com utilização de mini placa, parafusos e fio de cerclagem em ganso (Anser anser): Relato de caso. Acta Veterinaria Brasilica, 6:61-64.

Wander KW, Schwarz PD, James SP, Powers BE, Taylor B \& Wimsatt JH (2000) Fracture healing after stabilization with intramedullary xenograft cortical bone pins: a study in pigeons. Veterinary Surgery, 29:237-244.

West PG, Rowland GR, Budsberg SC \& Aron DN (1996) Histomorphometric and angiographic analysis of the humerus in pigeons. American Journal of Veterinary Research, 57:982986.

Williams R, Holland M \& Milton JL (1987) A comparative study of treatment methods for long bone fractures. Companion Animal Practice, 1:48-55.

Wissman MA (1999) New tools, diagnostics aid in bone and beak repair in birds. New Veterinary Products, 11:44-45. 